\title{
GRID COMPUTING FOR CLIMATE PROCESSING ON SOUTH AMERICA
}

\author{
Haroldo F. de Campos Velho ${ }^{1}$, Renata S. R. Ruiz ${ }^{1}$, Helaine C. M. Furtado ${ }^{1}$, Eugênio S. Almeida ${ }^{1}$, \\ Adriano Petry ${ }^{1}$, Phillipe O. A. Navaux ${ }^{2}$, Nicolas Maillard ${ }^{2}$, Guillermo Berri ${ }^{3}$, Mario Bidegain ${ }^{4}$, \\ Obídio Rubio ${ }^{5}$, Olivier Richard ${ }^{6}$, Roberto P. Souto ${ }^{7}$
}

\author{
${ }^{1}$ Instituto Nacional de Pesquisas Espaciais (INPE), Brazil. \\ ${ }^{2}$ Universidade Federal do Rio Grande do Sul (UFRGS), Brazil \\ ${ }^{3}$ Servicio Meteorologico Nacional (SMN), Argentina \\ ${ }^{4}$ Dirección Nacional de Meteorologia (DNM), Uruguay \\ ${ }^{5}$ Universidad Nacional de Trujillo (UNT), Peru \\ ${ }^{6}$ Laboratoire Informatique et Distribution (LIG), France \\ ${ }^{7}$ Laboratório Nacional Computação Científica (LNCC), Brazil
}

haroldo@lac.inpe.br, renata@lac.inpe.br, helaine.furtado@gmail.com, eugenio.almeida@cptec.inpe.br, dr.adriano.petry@gmail.com, navaux@inf.ufrgs.br, nicolas@inf.ufrgs.br, gberri@smn.gov.ar, bidegain.mario@gmail.com, obidior@yahoo.co.uk, olivier.richard@imag.fr

\begin{abstract}
The LAG-Clima project leads with web-computing environment for data-grid and processing-grid. The goal is to establish a computer network linking institutions on South America for climate prediction on meso-scale, and to share and analyze data. Software platforms: BRAMS meteorological meso-scale code, OurGrid middleware (grid computing), OAR system for managing the jobs.
\end{abstract}

Resumo: O projeto LAG-Clima quer estabelecer um ambiente de computação em grade de processamento e compartilhamento de dados. O objetivo é manter uma rede de interconexão entre instituições na América do Sul para previsão climática em meso-escala e disponibilizar dados. Plataforma de softwares: BRAMS (código meteorológico de meso-escala), OurGrid (computação em grade), sistema OAR para gerencia de tarefas.

\section{INTRODUCTION}

This paper presents a research development sponsored by some national agencies for funding: MINCyT (Argentina), CAPES (Brazil), CNRS (France), CONCYTEC (Peru), ANII 
(Uruguay). Among the goals of the project, we cite: connecting computer resources geographically spread, seasonal climate prediction on meso-scale, sharing data, and data analysis.

Applications in climate research require large amounts of data and computing power. For the execution of this type of applications on a grid computing environment, it is necessary to have available a tool for transferring and store the required files related to the climate data set. The OurGrid middleware is the software platform employed. The grid environment is designed for processing a climate prediction model on meso-scale domain, and for sharing observational and simulated data. The BRAMS (Freitas et al., 2007 - see also: www.ourgrid.org/) was selected as the meso-scale meteorological model. Two regions were chosen to study in the project: La Plata river basin, and the Peruvian Andes.

\section{GRID COMPUTING FOR CLIMATE}

One strategy for connecting computer centers is by using the grid environment. The Ourgrid middleware is adopted for the project. This software platform will be used as a processing grid, as well as a data grid.

OurGrid middleware is organized as shown on Figure 1: a user/client submits a job by a web-portal; the submission is stored in the "jobs database", and a job-scheduler is activated; after that the processing is executed using different processing nodes (or "grid nodes" - local nodes uses OAR system (Capit et al., 2005)), and the output returns to the database to be shared and/or visualized for the same or other users.

The OurGrid links remote grid-nodes and includes at least three components: (a) MyGrid: user interface for job submission; (b) OurGrid Peer: executed on the peer machine of each administrative domain from the grid, it provides different grid-nodes for job execution; (c) User Agent: a software installed on each local grid-node for executing jobs from the local peer machine/node. 


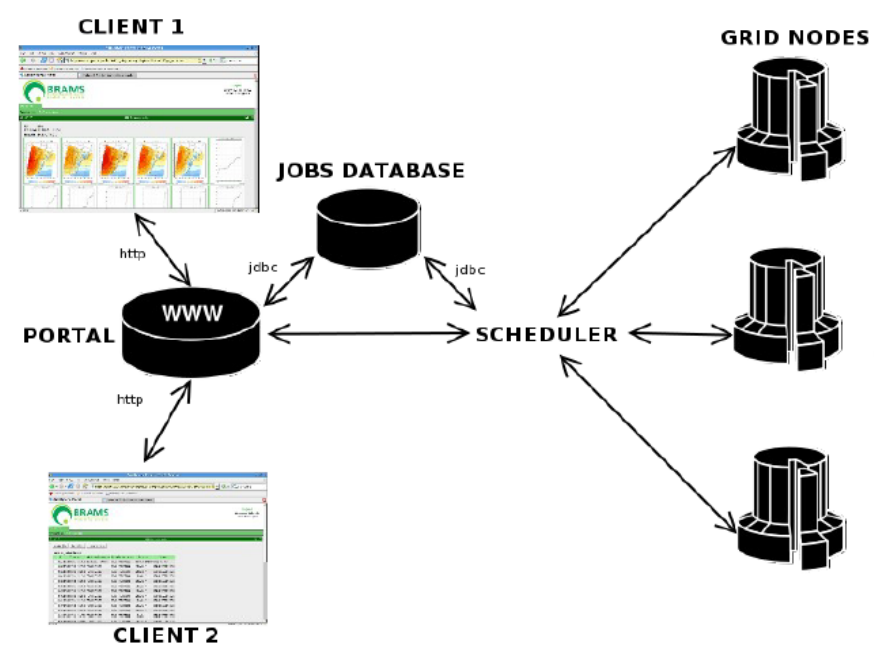

Figure 1: LAG-Clima grid architecture.

\subsection{PROCESSING GRID}

For grid, it is relevant to deal with low dependencies for data transfer, because the latency available today does not allow a fast information change using the internet. The ensemble prediction could be classified as a "bag-of-task". Such demand is appropriate to take advantage of a grid. The grid will be used to address two demands: compute the climatology for the two mentioned regions (initially 10 years), and operation for seasonal climate prediction on mesoscale.

\subsection{DATA GRID}

The grid environment can also be used to share, transfer, and data analysis. A database for meteorological information is based on PostgreSQL database package (Ruiz, 2103).

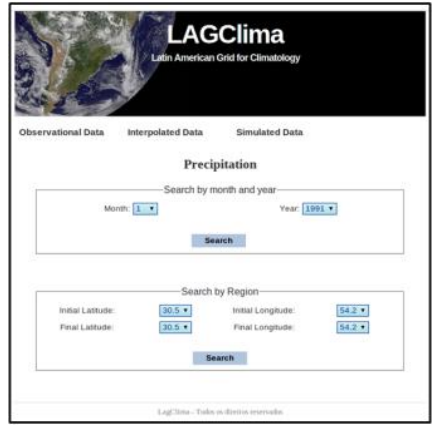

(a)

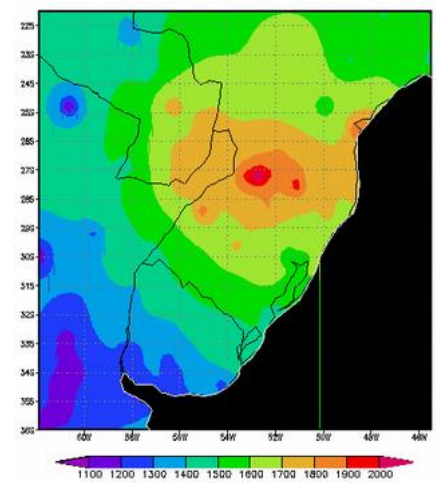

(b) 
Figure 2: Data Grid: (a) database on LAG-Clima web-site, (b) data analysis: Kriging monthly precipitation interpolation (example shown: 1991-2000 period - data from the meteorological services: Argentina, Brazil, Uruguay).

\section{REFERENCES}

Foster, I, Kesselman, C. The Grid: Blueprint for a New Computing Infraestructure. Morgan Kaufman Publishers, 1999.

FREITAS, S. R. et al. The Coupled Aerosol and Tracer Transport model to the Brazilian developments on the Regional Atmospheric Modeling System (CATT-BRAMS) $\neg$ Part 1: Model description and evaluation, Atmos. Chem. Phys., 9, 2843-2861, 2009.

LAG-Clima: http://gppd.inf.ufrgs.br/lagclima/data/analysis.html

CAPIT, N, COSTA, G. D., GEORGIOU, Y., HUARD, G., MARTIN, C., NEYRON, G. M. P., RICHARD, O. A batch scheduler with high level components. Proceedings of the International Symposium on Cluster Computing and the Grid (CCGRID), 776-783, Cardiff, UK,May 2005.

RUIZ, P. R. S. Integração de Bases de Dados Climatológicos Dispersas Geograficamente. Undergraduation report, FATEC, São José dos Campos (SP), Brasil, 2013.

PostgreSQL: http://www.postgresql.org.br/sobre. (accessed at 19/May/2013). 